IZA DP No. 6899

The Human Capital (Schooling) of Immigrants in America

James P. Smith

October 2012 


\title{
The Human Capital (Schooling) of Immigrants in America
}

\author{
James P. Smith \\ RAND Corporation \\ and IZA
}

\section{Discussion Paper No. 6899 \\ October 2012}

\author{
IZA \\ P.O. Box 7240 \\ 53072 Bonn \\ Germany \\ Phone: +49-228-3894-0 \\ Fax: +49-228-3894-180 \\ E-mail: iza@iza.org
}

Any opinions expressed here are those of the author(s) and not those of IZA. Research published in this series may include views on policy, but the institute itself takes no institutional policy positions. The IZA research network is committed to the IZA Guiding Principles of Research Integrity.

The Institute for the Study of Labor (IZA) in Bonn is a local and virtual international research center and a place of communication between science, politics and business. IZA is an independent nonprofit organization supported by Deutsche Post Foundation. The center is associated with the University of Bonn and offers a stimulating research environment through its international network, workshops and conferences, data service, project support, research visits and doctoral program. IZA engages in (i) original and internationally competitive research in all fields of labor economics, (ii) development of policy concepts, and (iii) dissemination of research results and concepts to the interested public.

IZA Discussion Papers often represent preliminary work and are circulated to encourage discussion. Citation of such a paper should account for its provisional character. A revised version may be available directly from the author. 


\section{ABSTRACT}

\section{The Human Capital (Schooling) of Immigrants in America*}

This paper deals with several salient issues about immigrants to the United States and their education. These issues include a comparison of the schooling accomplishments of immigrants and the native-born that emphasizes the considerable diversity in the schooling accomplishments among different immigrant sub-groups and between legal and undocumented migrants. I also examine the role of the foreign-born who come to the United States for post-secondary schooling. Finally, I show that the educational generational progress among all groups of immigrants to the United States has been quite impressive during the $19^{\text {th }}$ and $20^{\text {th }}$ centuries.

JEL Classification: $\quad 120,123, \mathrm{I} 28, \mathrm{~J} 10, \mathrm{~J} 15, \mathrm{~J} 61$

Keywords: immigration, education

Corresponding author:

James P. Smith

RAND Corporation

1776 Main Street

PO Box 2138

Santa Monica, CA 90407

USA

E-mail: smith@rand.org

\footnotetext{
* This paper is the first draft of a chapter that is scheduled for inclusion in The Handbook on the Economics of International Migration, edited by Barry R. Chiswick and Paul W. Miller, and to be published by Elsevier in their Handbook Series in 2014. The research was supported by grants from $\mathrm{NIH}$. The expert programming assistance of David Rumpel and Iva Maclennan is gratefully appreciated.
} 


\section{Introduction}

Education and immigration have always been tightly linked in American history. Many immigrants came to the United States, at least temporarily, to attend American schools or because they believed that American schools offered the best opportunity for economic advancement for their children. In the economics literature, schooling of immigrants was the primary index of immigrant skill in the labor market so that trends in the labor market 'quality' of different waves of immigrants largely amounted to comparing trends in immigrant education compared to that of the native-born. As the price of skill (the income returns to schooling) varied over time and between the United States and the main sending countries, the incentives of people with different amounts of education to come to the United States would change. ${ }^{1}$

This influence of immigrants on the average skill of the American work force has always been both direct and indirect. Immigrants are not only a growing fraction of today’s workforce-as they have been throughout American history — they will also be parents and grandparents of a significant part of the American labor market in the future. Thus, the issue of the size of intergenerational transmission of schooling across immigrant generations is a basic determinant in shaping what the country will look like in the decades ahead.

This paper is divided into five sections. Section 1 documents the most salient comparative patterns in the schooling of the foreign-born population in the United States, while the second section examines how nativity differences in education have changed over time. Section 3 highlights the considerable education diversity that exists in schooling accomplishments within the immigrant population. This diversity spans time of arrival, ethnic background, legal status, and the reasons for admission to the United States. Section 4 addresses the issue of the impact of foreign students on American schools. The final section focuses on the inter-generational transmission of schooling. 


\section{Schooling of Migrants and the Native-born}

Using data obtained from the 2010 and 2002 Current Population Surveys (CPS), Table 1 highlights differences in education distributions between three groups — the foreign-born, the nativeborn, and the recent foreign-born (those arriving in the United States within the last five years). This table also illustrates how those education distributions changed over the first decade of the $21^{\text {st }}$ century. I will highlight long-term changes below. Table 2 presents the same three-way division from the 2010 and 2002 CPS for the principal ethnic origin classifications of people currently living in the United States_-Asians, Europeans, and Hispanics. ${ }^{2}$ Combined, these two tables reveal the principal salient facts about the comparative education attributes of migrants in the recent past.

On average, immigrants to the United States have less schooling than the native-born American population does_-in 2010, for example, the mean migrant deficit in education was 1.3 years of schooling. Among recent migrants, the education deficit was even smaller-about one year less education. This migrant education deficit is slightly higher among women compared to men. American-born men and women have precisely the same amount of schooling, while female migrants trail male migrants by about one-tenth of a year of schooling.

Far more dramatic than these average education differences by nativity, however, are differences within the lower and upper part of the education distribution. Consider first those at the bottom tail of the education distribution. About $18 \%$ of the foreign-born $(16 \%$ among recent immigrants) had only an elementary school education or less, more than six times the comparable proportion among the native-born. Among recent immigrants in particular, however, the relative ranking actually shifts within the top part of the education distribution where $14 \%$ of recent migrants had more than a college degree compared to $10 \%$ of those born in the United States. 
When we compare the education distributions in the 2010 and 2002 CPS in Table 1.A and 1.B, we see small steady increases in education accomplishments for all three of our groups-the native-born, the foreign-born, and the recent foreign-born. On average, all three groups experienced about three-tenths of a year increase in mean years of education, with almost no change at all in the comparisons among the groups based on their native or foreign-born status.

These education differences between native and foreign-born populations pale next to the heterogeneity that exists within the migrant population to the United States. That diversity already is hinted at by the comparatively fat tails of the foreign-born education distribution in Table 1 . But the heterogeneity becomes even starker in Table 2, which offers comparison among the three principal types of immigrants who come to the United States based on their region of origin (Asians, Europeans, and Hispanics) using the 2010 (Table 2.A) and 2002 (Table 2.B) CPS to classify their place of birth.

Not surprisingly, differences amongst these broadly defined ethnic groups are very large. On one end are recent European and Asian migrants who actually are more educated than native-born Americans by a half a year of schooling on average. Very few recent European migrants to the United States are low skilled, and 16\% claim some post-baccalaureate schooling (compared to 10\% among all native-born Americans).

Using schooling as the skill index, Asian migrants score even better. On average, they too are relatively high skilled, albeit with more within-group diversity than the Europeans. While 22\% of recent Asian migrants have schooling beyond a college degree, 9.5\% have an $8^{\text {th }}$ grade education or less. Both proportions are higher than those for native-born Americans. On the other end of the education skill index lie Hispanic migrants. On average, Latino migrants are much less skilled than the native-born or than either European or Asian migrants are. To provide a dramatic illustration, 
among recent migrants Europeans and Asian have almost four years of schooling more than Latino migrants do. The reason is simple—about 30\% of recent Latino migrants have only eight years of schooling or less.

If we compare the distributions in Table 2.A and Table 2.B, we see that over the last decade the education accomplishments of the average recent Hispanic immigrant has been rising while that of both Asian and European recent immigrants has been declining. The overall increase in the education of recent immigrants during the last decade was also due to the rising fraction of migrants who came from European or Asian countries where the average education of migrants was higher. These recent trends indicate that the differences among recent migrants has been narrowing somewhat. During the last decade, the education gap of new Hispanic migrants compared to Asian and European recent migrants fell by about a year of schooling.

This simple summary highlights salient differences in schooling achievements of the native and foreign-born. On average, new migrants are about a year or so less educated than the typical native-born American. However, the real differences emerge in the tails. Migrants are simultaneously more likely to be considerably more educated (post-baccalaureate schooling) and less educated (without a high school diploma) than are native-born Americans. A good deal of those differences are differentiated in the three major ethnic groups—compared to native-born Americans, European and Asian migrants are far more likely to have training beyond college while Latino migrants are far more likely not to have gone beyond elementary school.

Before examining whether these schooling differences between native and foreign-born can be explained by a few crucial theoretical and/or institutional factors, I next examine a closely related question—what has happened to these educational disparities by nativity over time? 


\section{The Changing Education Gap of Immigrants}

A primary concern in the economics literature is the changing labor market quality of foreign immigrants to the United States (see Borjas, 1994, 1995; Jasso, Rosenzweig, and Smith, 2000; Smith, 2006b). Education continues to be the most basic index of skill so it should come as no surprise that this topic has focused on education gaps of migrants compared to the native-born. The discussion often begins with a rapidly changing ethnic composition of migrants to the United States.

Before the Immigration and Nationality Act amendments of 1965 repealed the national-origin quotas, Europe and Canada were the dominant sources of immigrants to the United States. Even as late as 1950, 90\% of the foreign-born population was of either European or Canadian heritage. But with the passage of the 1965 amendments, country of origin composition changed dramatically. In 2010, those born in Europe represented only 12\% of the foreign-born in the United States.

The two principal changes subsequent to the 1965 ACT involved increasing flows of migrants from Asia and Latin America. Especially for Latinos, these numbers were augmented by considerable influxes of unauthorized migrants. Foreigners from the Caribbean and Latin America were one-in-five of the foreign-born in 1970 and $53 \%$ by $2010 .^{3}$ Finally, Asians went from only $3 \%$ of the foreign-born in 1950 to a quarter by $2010 .{ }^{4}$

While the 1965 amendments represented the most substantial change in immigration policy in the last 50 years, other subsequent legislation had significant impacts on attributes of migrant flows. Among the two most important were the 1986 Immigration Reform and Control Act (IRCA) and a series of laws that encouraged entry of more skilled immigrants. ${ }^{5}$

Besides attempting to limit future illegal immigration by adding more resources for border control and by establishing employer sanctions, IRCA created a program for legalizing illegal aliens already residing in the United States. Almost 3 million unauthorized migrants were legalized through 
this program (see Smith and Edmonston, 1997). The most important of the recent changes in legal admission policy was the Immigration Act of 1990, which simultaneously reduced the number of visas for unskilled migrants while increasing them for skilled immigrants.

Table 3 documents trends by listing for each of the decennial Censuses between 1940 and 1990 and for the 1996, 2002, and 2010 CPS mean education levels of native and foreign-born populations over age 24. To capture changing flows, means are also presented for the foreign-born population who arrived during the last five years in each data source. Once again, separate data are presented for the three principal broad ethnic groups-Asians, Europeans, Hispanics_-and, given their importance, separately for Mexican migrants. ${ }^{6}$

Education levels have moved steadily higher over time for all groups in Table 3. Each decade witnessed another increase in schooling accomplishments for our reference group - the U.S. nativeborn-although the pace of change has slowed in recent decades. The cumulative change was eventually large - essentially moving the typical adult native-born American from an elementary school graduate in 1940 (8.8 years) to going beyond high school in 2010 (13.6 years). In the last 20 years, mean schooling advanced by about a year among the American native-born compared to 1.8 years during the previous 20 year period between 1970 and 1990.

While starting at a lower base (a deficit of two years in 1940), the foreign-born population has not only moved lockstep with the native-born, but eventually their cumulative change was even greater, reducing their education deficit with the native-born to one and a third years by 2010. No doubt reflecting secular improvements in education in the sending countries and increasing selectively of migrants, recent immigrants tend to have more schooling than the complete resident foreign-born population. However, the education gap between them has narrowed considerably so 
that time series gains in education among the recent foreign-born are smaller than that of all migrants.

Differences in education by region of origin are large with Latino and especially Mexican migrants lagging behind the others by a significant margin. Given the better educational opportunities available in the United States compared to many of the sending countries, it is not a surprise that within each ethnic group the native-born tend to have more schooling than their foreignborn counterparts. In fact, the differences among ethnic groups are far smaller in the native-born population than the foreign-born, an indication of convergence across descendants of immigrants.

To make trends in disparities with the native-born population more transparent, Figure 1 plots the extent to which schooling of the native-born population exceeds that of the total and recent foreign-born population. Using the same reference group of total native-born population, Figure 2 displays disparities in mean schooling of the different native-born ethnic populations; Figure 3 the differentials for ethnic specific foreign-born populations; and Figure 4 education gaps for recent immigrants.

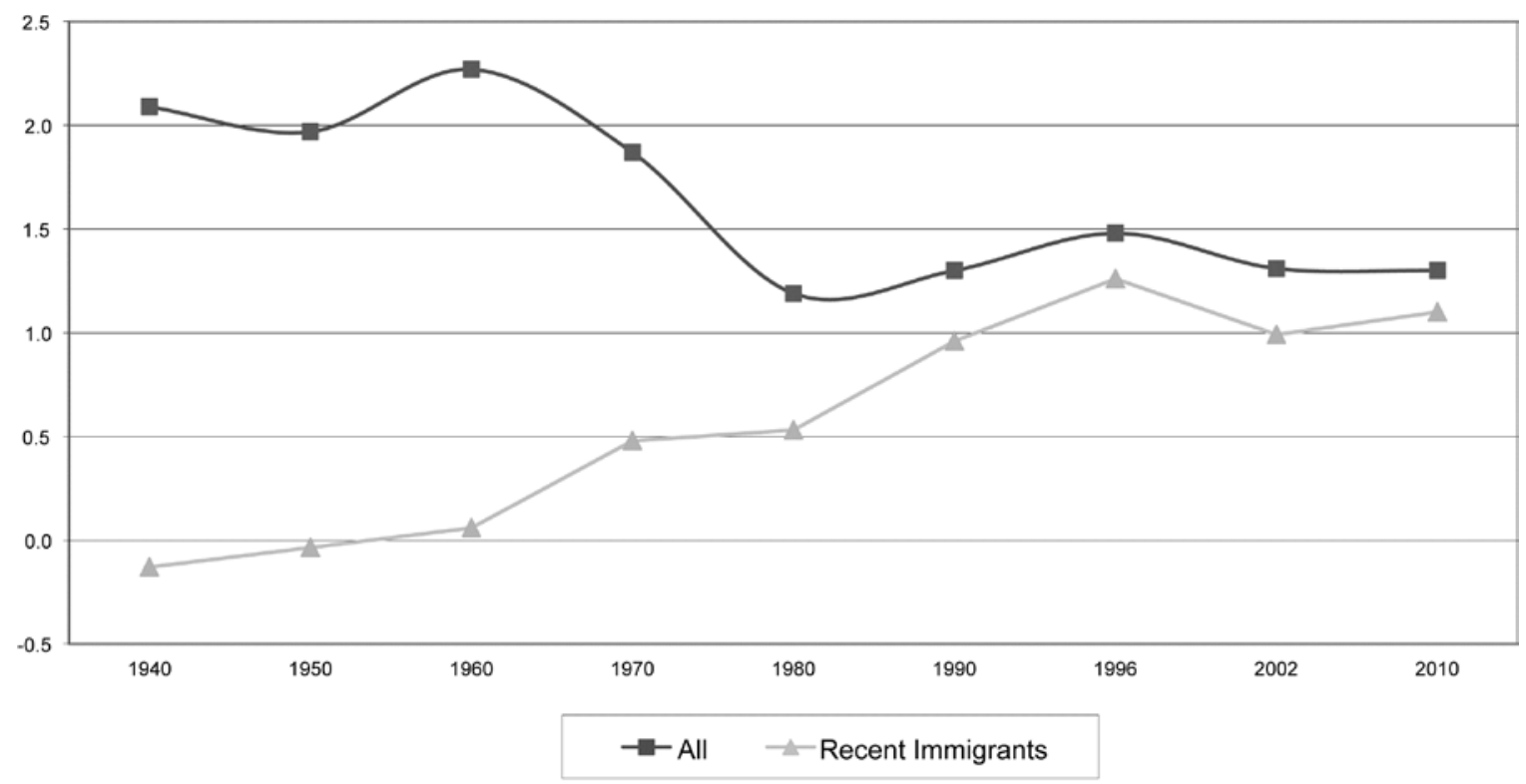

Fig. 1. Schooling Disparity of All Foreign Born (comparison group: All Native Born) 
Putting aside within-ethnic group trends, two things are particularly striking concerning schooling deficits of the foreign-born in Figure 1. First, up to 1980 the schooling disadvantage of the total foreign-born population was declining while it was simultaneously increasing for new recent immigrants. Since the total foreign-born represents the stock of immigrants at a point in time while recent immigrants capture recent flows, these opposing stock-flow trends are not a contradiction. The stock of migrants is weighted heavily by history toward trends for past European migrants. Education increases between Censuses are largely due to older, less-educated immigrants dying off. The labor force skill of migrants is much better represented by the stock (all) in Figure 1 and over the 70-year period the skill of migrants has actually been improving.

Figure 2 summarizes trends for various native-born populations. Compared to the overall average, the native-born of European descent have slightly less than a half-year advantage, ${ }^{7}$ while those of Asian background hover around with a year of schooling advantage. What is remarkable about both Europeans and Asians is how little trend exists in this ethnic gap of the native-born. There is a more detectable steady decline in the schooling gap of native-born Latinos until it is about a third as large now as it was in 1940 so that the differences between Latinos and their European and Asian immigrant counterparts has been declining steadily over time.

Figure 3 plots education gaps for the full foreign-born populations for each ethnic grouping. In 1940, all groups start out with a schooling disadvantage — about two years for Europeans and Asians and twice that much for Hispanics, and almost five years for Mexican immigrants. Subsequently, first for Asians and then for Europeans, these schooling deficits narrowed until currently the total adult foreign-born populations of both groups hold a narrow advantage of the U.S. native-born. In comparison, there is very little change between Hispanics and Mexicans where the 


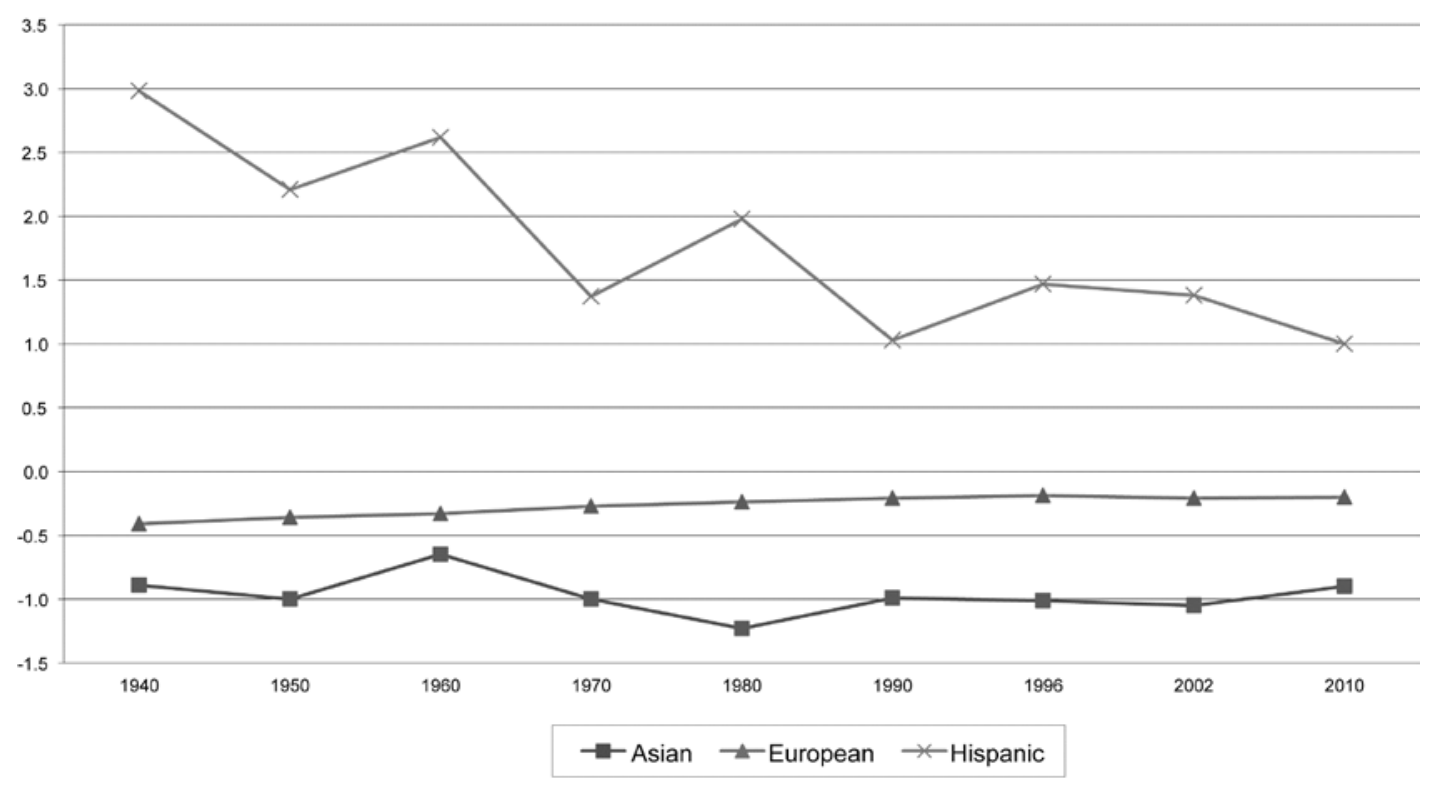

Fig. 2. Schooling Differences of the Native Born (comparison group: All Native Born)

education gap among the foreign-born at best drifts slightly downward, especially in the last decade and a half. Thus, the overall downward trend in the foreign-born education gap results from a narrowing gap between Asians and Europeans, a slightly falling gap among Latinos which combined offset any effect of a shift in relative representation toward Hispanics.

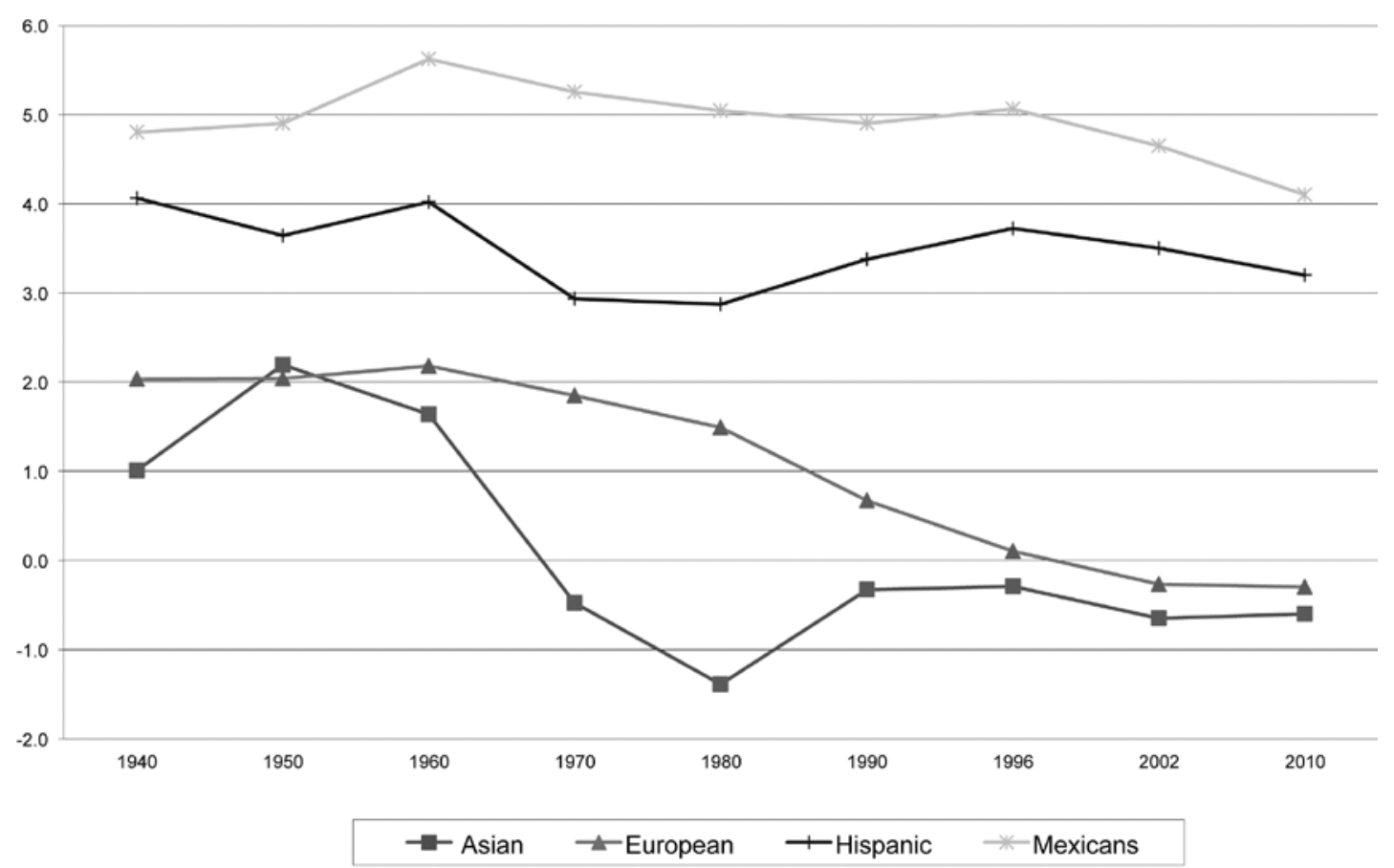

Fig. 3. Schooling Disparity of All Foreign Born (comparison group: All Native Born) 
Figure 4 presents the same type of data for recent immigrants. Typically, new Asian and European migrants have had more education than the native-born, an advantage that in 2010 is about the same for both groups. After 1996, the education gap for new Latino migrants experienced a slight closing of the education gap.

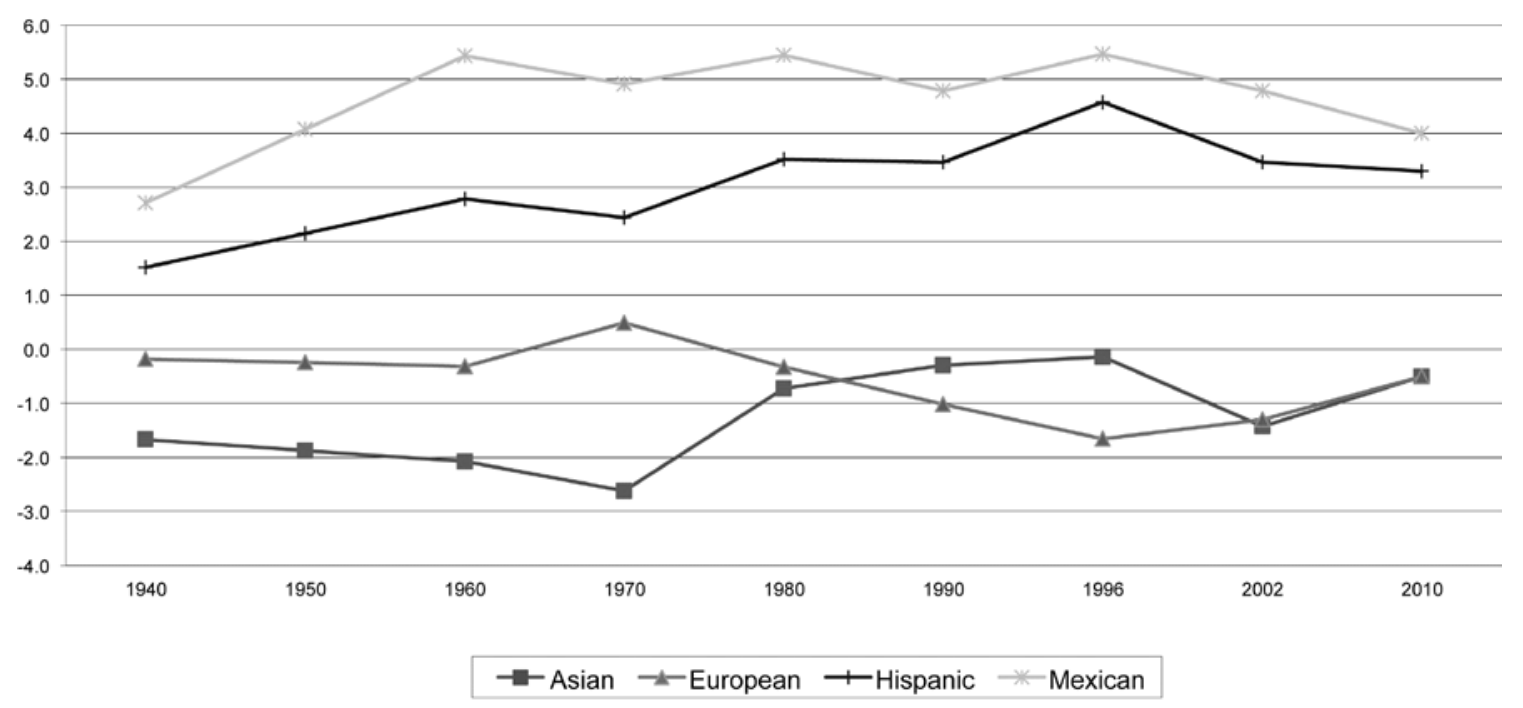

Fig. 4. Schooling Disparities of Recent Foreign Born (comparison group: All Native Born)

Since they directly capture flows, data on recent immigrants in Figures 1 and 4 are more sensitive to period changes in legislative and economic incentives in the propensity of foreigners to migrate to the United States. A comparison of the more stable within-ethnic group trends in Figure 4 compared to the slightly widening gap of recent migrants in Figure 1 suggests that the principal impact of the 1965 legislative change was on the composition of migrants -increasingly the representation of less-schooled Latino migrants since there is little within-ethnic group trend. Two largely offsetting forces dominated the recent period. On one hand were the legalization of mainly Hispanic migrants through IRCA and the increased flows of unauthorized (again mainly Hispanic) migrants who have less schooling than the average native-born American. On the other hand, there were increased numbers of European and Asian migrants who have education above that of the typical native-born American. 
An attempt to highlight trends during the 1990s is provided in Table 4, which lists mean schooling of migrants by year of entry into the United States using the 1996, 2002, and 2010 CPS. Among all migrants in 2010, there is a u-shaped pattern with higher schooling levels among pre1990 migrants compared to those who came between 1990 and 2005, and then a subsequent half a year rise. Within ethnic groups, the education of Asian and European migrants has been falling since the mid-1990s. There is little evidence of much of a trend at all among Mexican migrants.

Since data are provided in earlier CPSs for the immigrant cohorts who entered during the 1990s, Table 4 allows one to examine the same entry cohort of immigrants six to eight years apart. Within ethnic groups, mean schooling is higher in the more recent 2010 CPS. For example, consider Asian migrants who arrived between 1990 and 1996. They reported 12.8 years of schooling in the 1996 CPS, but by 2010 this had risen to 14.6, an increment of .two years. While increases for other ethnic groups exist, they often run about half a year of schooling.

There are several possible reasons for this upward drift in mean schooling within entry cohorts. It may simply reflect 'grade' inflation, a well-documented trend in census data even for the native-born. Second, it may be produced by the aging of young, more educated immigrants who were 19-24 years old in 1996 but who now qualify for the 25-year-old age restriction by 2002, and the exit of older immigrants with low schooling levels who died between 1996 and 2002. Third, it could reflect migration selection effects if less-educated migrants are more likely to return even temporarily to the sending countries. Circulatory migration of the less educated would produce this pattern since the less educated would be less likely to remain within any specific time since migration interval in successive CPS surveys. Finally, some part of this upward drift may be the consequence of additional post-migration school attendance.

To obtain some notion of the importance of the second and at least a component of the fourth 
reason, schooling differences with the native-born were calculated for a sample restricted to those aged 31-55 in 1996 and 37-61 in 2002. The younger age threshold of older migrants mitigates against any significant mortality effect while the older age cutoff among the young should reduce the impact of school completion among younger migrants. Finally, the upward adjustment in the age cutoff of the young eliminates the impact of the new entry by 2002 of younger migrants who failed to meet the age threshold in 1996. Schooling increments within time since immigration intervals were only marginally different in this sample suggesting that these demographic factors of mortality and 'aging in' are not the major part of the story.

The exclusion of those factors leaves grade inflation, post-migration education selectivity, and post-migration education accumulation as the major options. Some insights into the latter are provided by Table 5, which lists the fraction of new legal immigrants in 2003 who received some type of education during the year after the receipt of their green cards. The second column lists the fraction of respondents who received some form of training during this period, while the next five columns describe the type of training that took place.

The extent of post-green-card training and schooling is impressive. A fifth of all new legal immigrants attended school after receiving their green cards. This schooling consisted largely of attending regular schools (especially for those in their 20s), and taking language classes (especially among older new-green- card recipients). Thus, it seems quite likely that some significant part of this rise in schooling between successive surveys is real—new immigrants do add to their schooling after receipt of their green card. But this also seems unlikely to offer a complete explanation. The data in Table 4 show that this increase in mean education takes place even among immigrants who arrived much earlier. By this time, one would have thought that the incremental schooling behavior would have run its course. 
This suggests mostly by default that differential out-migration (temporary or permanent) of less-educated migrants may be an important and underappreciated phenomenon. Greater circular migration alone of less-educated migrants (which seems likely to have taken place) would produce across-year increases of schooling of migrants arrayed by their year of migration. If so, this also implies that the use of the analytical procedure of comparing immigrants stratified by reported time since arrival across surveys taken in different calendar years may be a perilous exercise in spite of how widespread this practice is in the literature.

Several things are clear from this analysis. First, cross-sectional patterns associated with time since immigration may be a quite poor way of assembling evidence for either assimilation or immigrant quality. It is well recognized to be inappropriate when assessing the amount of assimilation since they are obviously members of different cohorts. It may also be problematic for assessing cohort quality as there may be significant post-immigration changes in the composition of entry cohorts as well as their schooling.

Second, periodic changes in immigration legislation have had important effects on the skill composition of subsequent immigrant cohorts. The most well documented example concerns the impact of the 1965 National Origin Quota Act, which resulted in a large shift in the ethnic composition of immigrants with fewer Europeans and relatively more Asians and Latinos coming to the United States. During the 1970s and 1980s, this shift toward increasing numbers of Latino immigrants in particular led to an increasing gap between the average education of new immigrants compared to that of the native-born.

\section{The Educational Diversity of Migrants}

The foreign-born population represents a combination of very different types of people- 
legal immigrants, legal nonimmigrants (those with visas that authorize stays for limited periods of time), and unauthorized or illegal immigrants. These populations have been historically distinct in many ways, not the least of which is their education. For example, many student visa nonimmigrants come to the United States attracted by its reputation for superior post-secondary schools. That trend has accelerated in recent decades. In contrast, many illegal immigrants typically worked in jobs within the bottom tail of the skill distribution, especially in the service and agricultural sectors. Not surprisingly, their schooling is often far below those of most American workers. Finally while legal immigrants come to America for many diverse reasons reflecting the heterogeneous visa categories that allow them to come to the United States, especially in recent years some qualify for permanent residence only because they are highly skilled and highly educated. Data on average education of the foreign-born population may be quite sensitive to the relative proportions of these diverse groups of immigrants, and aggregate data may poorly describe each of them.

There were 306 million people living in the United States in 2010. Of these, 40.2 million or one in eight were born in another country (Passel and Cohn, 2011). While making distinctions is difficult and measurement is far from perfect, current estimates indicate that roughly 27 million of the foreign-born (or about 68\%) were prior legal permanent immigrants to the United States.

Who are the rest? About 1.7 million were legal nonimmigrants. The remainder of the foreignborn are obviously the most difficult to count, but recent estimates indicate that there are 11.2 million unauthorized residents (Passel and Cohn, 2011). Moreover, the relative proportions of these groups vary significantly across ethnic groups. For example, recent estimates claim that among all foreign-born in the 2010 Census, $29 \%$ were unauthorized. The corresponding fraction unauthorized for the Mexico-born population was 58\%, while for those from India or China the fraction unauthorized was $13 \%$. 
Hard data documenting the distinct education attributes of these different subgroups of the foreign-born are almost nonexistent, especially if we strive for nationally representative statistics. The reason is simple—-there has been no complete attempt to directly identify in surveys to which of the three groups a foreign-born respondent belongs. Indirect estimates are possible since at least one of the three main sub-populations can be separately identified. The New Immigrant Survey (NIS) was a stratified random sample of new immigrants admitted to legal permanent residence in the United States, i.e., granted green cards during 2003. Since the NIS samples legal immigrants only, any discrepancy between say the CPS and NIS schooling distributions among recent immigrants would reflect the presence of illegal migrants and legal nonimmigrants in the CPS.

Table 6 depicts the distribution of schooling of the entire adult 2003 NIS cohort, along with corresponding data based on the 2003 CPS for the foreign-born who entered the United States between 1998 and 2003 ('recent foreign-born'). The 2003 CPS is used because it is the same calendar year as the 2003 NIS. These data are also presented for three subgroups—Hispanics, Asian, and Europeans. The Hispanic sub-group is also divided into 'recent' non-Mexican Hispanics and 'recent' Mexican-born migrants to the United States.

Compared to the CPS recent foreign-born population which includes all three broad categories of immigrants (legal, temporary, and undocumented), while mean education is very similar there are far more legal immigrants at the top and bottom of the educational hierarchy. Thus, there is much more heterogeneity within the legal immigrant population compared to all recent foreign-born population in the CPS. The pro-skill component of the new legal immigrant population appears as $19 \%$ of new legal immigrants have more than a college degree in 2003 compared to a CPS recent foreign-born population almost half as large (11.4\%). At the same time, legal immigrant rules 
for admission into the United States also draws $10 \%$ of its new flows from those with less than five years of schooling compared to $6 \%$ in the CPS.

This comparison varies a good deal across the main immigrant ethnic groups. Not surprisingly, there are large differences in average schooling between our main ethnic groups. Among new legal immigrants, Mexicans trail Asians by four and a half years of schooling and new European legal migrants by more than six years of schooling on average. Even within the Latino new legal immigrant group, Mexicans have two and a half fewer years of schooling than non-Mexican Hispanics. Similar education disparities by region of origin exist in the 2003 CPS.

Education diversity within our immigrant ethnic groups is impressive. Forty-two percent of new Mexican legal migrants have only elementary schooling or less compared to 6\% of Europeans, 8\% of Asians, and about 20\% of non-Mexican Latinos. Similar ethnic differences exist at the top of the education distribution. Now new legal Asian immigrants lead the way with $21 \%$ of them having more than a college degree. The comparable fractions for European, non-Mexican Hispanics and Mexicans are $18 \%, 6 \%$, and $2 \%$ respectively.

From where does this heterogeneity in education accomplishments of new legal immigrants derive? Legal immigrants come into the United States because they qualify in at least one of a very complex set of rules governing legal admission. Table 7.A illustrates the source of this diversity by presenting for the 2003 New Immigrant Survey average education by the type of visa that qualified one for legal immigrant status. Alongside these visa-specific mean education levels are placed the percent of people who qualified for legal admission in each of the visa categories listed in the first column. In order to track recent trends in admissions, data for the 1996 Legal Immigrant Sample are contained in Table 7.B using the same format as in Table 7.A. 
Variation in education by type of visa is enormous with a range of nine years of schooling from the highest to the lowest visa category in Table 7.A for the full sample of new legal immigrants. The most fundamental distinction involves those who were admitted on employment visas compared to those who arrived on family visas, with the former type of immigrant typically being much more educated. Compared to family-based visa categories, there is a distinct pro-skill bias to those admitted on employment visas (Jasso, Rosenzweig, and Smith, 2000). The least-educated category are parents who typically did not complete elementary school, while the best educated are those new immigrants who came on employment visas who on average were college graduates. The influence of positive assortative mating in the marriage market is also evident in the ranking of schooling of those admitted through spousal visas; at the top employment (15.7), followed by spouses of U.S. citizens (13.4), and finally spouses of permanent residents (8.0). This variation by visa type is important because over time legislation has loosened or tightened the numerical limits on different types of visas. The most important of these changes in the last two decades is the increase in numerical limits on employment visas which resulted not only in increased entry of those with employment visas but also in an increase in the average skill of education of legal immigrants (see Jasso, Rosenzweig, and Smith, 2000).

The diversity in visa class of admission varies greatly by ethnic group. On one extreme, almost three-quarters of new legal Mexican immigrants consist either of spouses (55\%) or parents (22\%), while only $3 \%$ qualified using employment visas. In contrast, 33\% of new Asian immigrants in 2003 had employment-based visas and 28\% qualified on marriage visas. Asians are also unique in that they are the only ethnic group in Table 7.A in which there were more new arrivals compared to adjustment legalizations of those already residing in the United States. This most likely reflects the 
distances involved, and the more recent increases in flows of Asian immigrants into the United States.

If we compare Tables 7.A and 7.B, the visa categories that had the largest decline in average education between 1996 and 2003 were in the two family categories—-parents of U.S. citizens (10 to 8 years of schooling) and siblings (from 13.5 to 11.7). The parents of Mexican immigrants in particular were poorly educated in the 2003 class of legal immigrants - 3.5 years of schooling on average. The other factor that appears to have played a role in lowering the mean education of new legal immigrants between 1996 and 2003 was the expansion in the ‘other legalization’ category, a category that eases immigration largely of those in Central and South America (for example, El Salvador and Nicaragua) and cancellation of previous deportation status. As the data in 2003 demonstrate, on average this category has an elementary school education.

\section{Foreign Students at American Schools}

Education plays several roles in influencing who comes to the United States. Education affects earnings opportunities in the host and sending countries and therefore alters the incentives about which types of people want to migrate to the United States. In addition, higher education in particular is a product in which the United States has had historically a distinct comparative advantage. The growing worldwide desire to attend American universities represents a strong draw to foreign nationals to live in the United States for at least some period of time. Attendance at U.S. colleges and universities is thought by some to be a way station to subsequently obtaining legal permanent residence in the United States. Foreign students attending schools in the United States must obtain temporary visas for the duration of their status as students and are legally classified as nonimmigrants. ${ }^{8}$ 
Figure 5 plots time series trends in total number of nonimmigrants admitted to the United States along with total numbers on temporary tourist or business visas and those on student visas. Globalization has a human dimension, as mirrored in the accelerating numbers of nonimmigrants admitted to the United States in recent decades. Since 1960, the numbers of nonimmigrants to the United States have grown from about 1.1 million in 1960 to almost 40 million by 2009. Figure 5 indicates that most of this overall surge is accounted for by a single group — those on temporary visas for tourism or business — who comprised $90 \%$ of all nonimmigrants. ${ }^{9}$ There was not much of a recent slowdown as numbers of nonimmigrants basically doubled during the 1990s — that is until September 11. In that calendar year and for a few years thereafter, the number of nonimmigrant visas fell by almost 5 million. In the years subsequent to 9/11, numbers of non-immigrant flows have recovered and exceeded their pre-9/11 levels and seem to be back on trend.

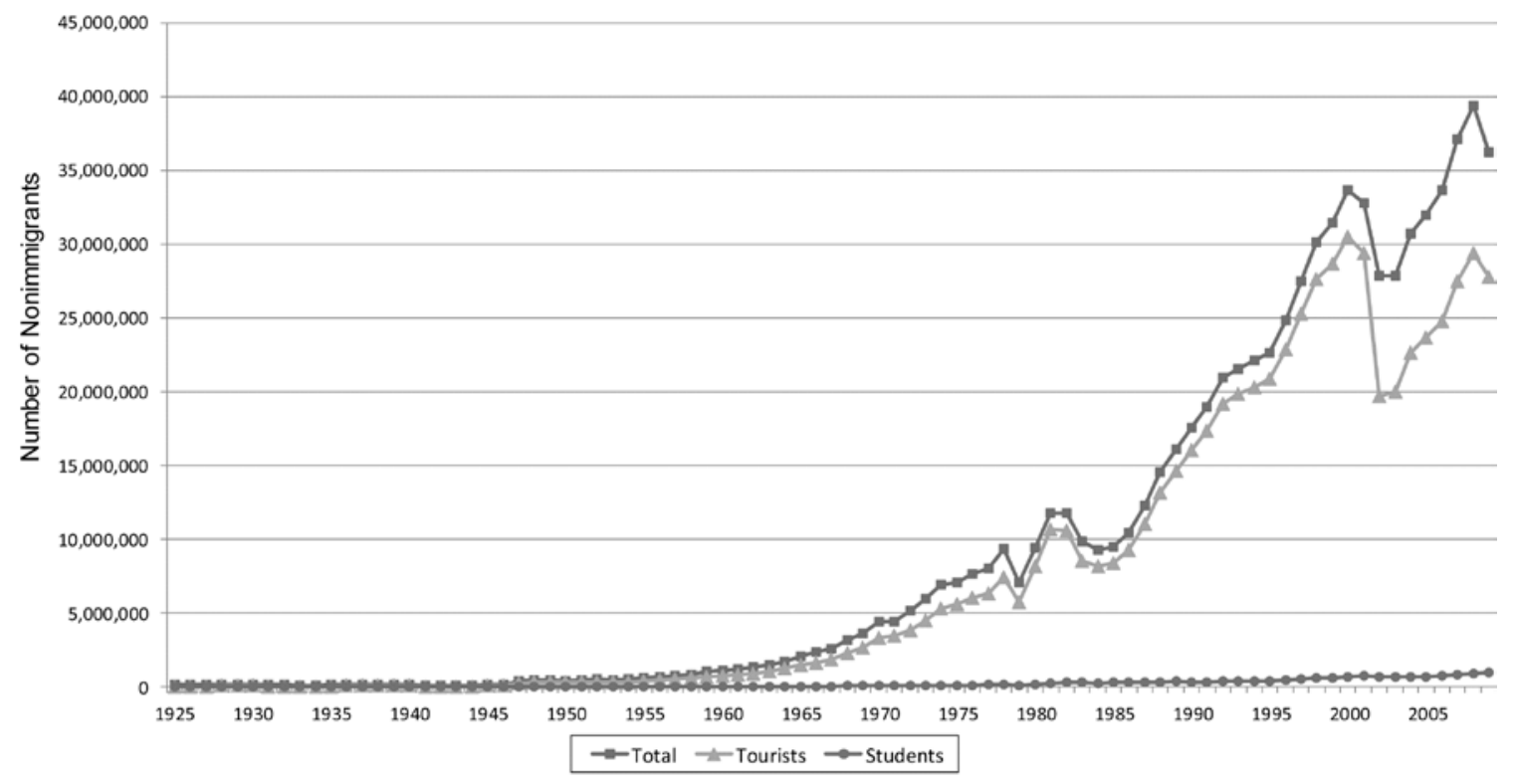

Source: Historical Statistics of the United States, Millennial Edition, R. Bache, S. Carter, and R. Sutch (eds.), 2006; and 200/ Statistical Yearbook of the Immigration and Naturalization Service.

Fig. 5. Nonimmigrants Admitted, 1925-2009

When placed on the same scale as all nonimmigrants in Figure 5, secular trends for foreign students are barely detectable as they only comprise about $2 \%$ of the total. However, when plotted in 
Figure 6 on a scale more appropriate to their numbers, we see that the same rapid secular expansion occurred with foreign student visas. Student visas reached three quarters of a million in 2001, more than double the number in 1990 and more than seven times that in $1970 .{ }^{10}$ Once again the events of 9/11 had a detectable negative impact on these trends, but that impact now appears to have been completely temporary.

Another way of gauging the importance of foreign students is to compare them to the size of the total student population. Table 8 does that by listing the percent of all enrolled students who are foreign nationals. In spite of the growth in student visas, the overall numbers remain modest—about 3.4\% of students at American colleges and universities are foreign nationals. Foreign student representation varies a great deal by level of schooling and field of study. As Table 8 demonstrates, less than $3 \%$ of undergraduates are foreign students, while about one in nine of those attending American graduate schools are foreign students.

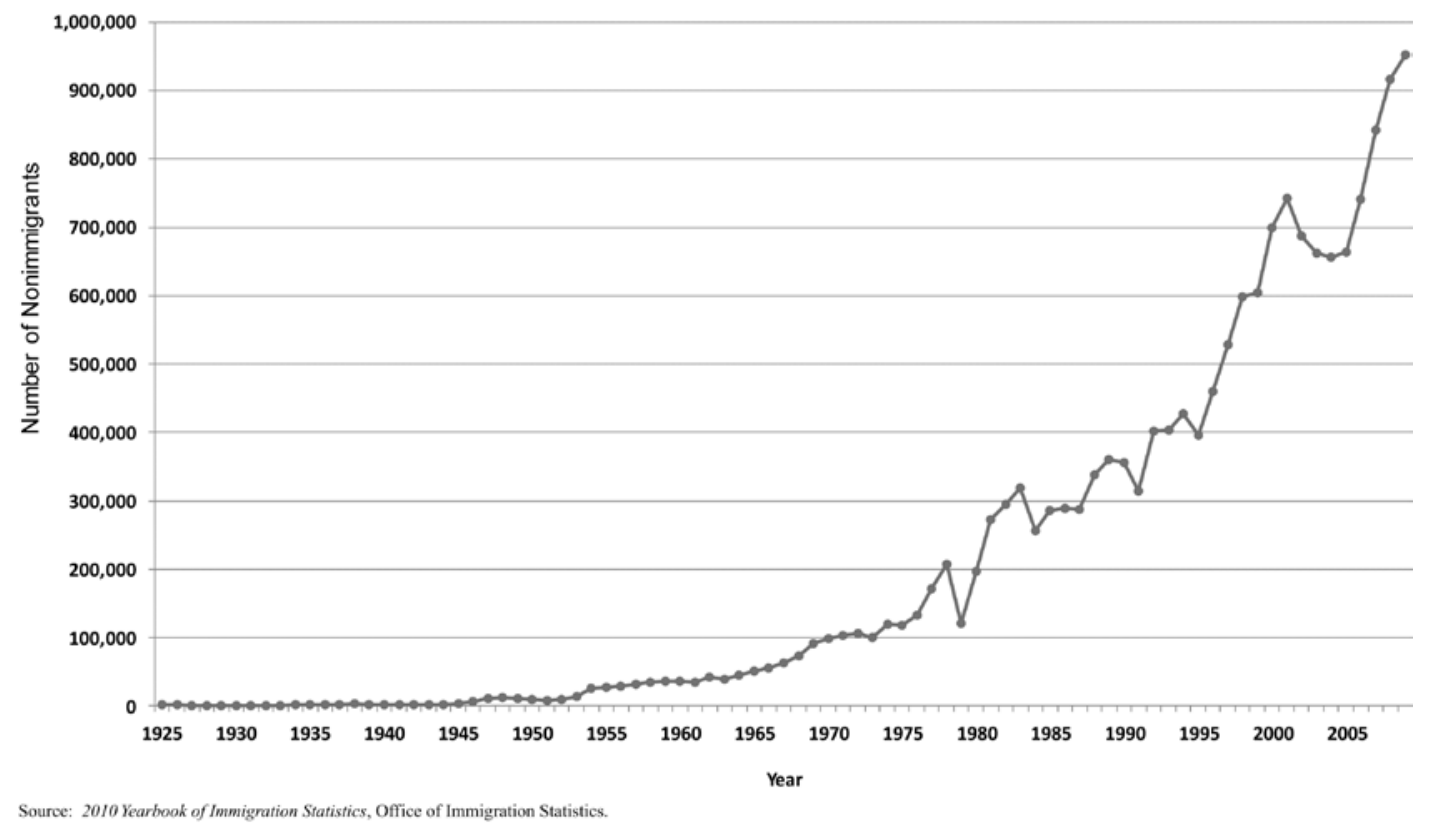

Fig. 6. Nonimmigrants Students, 1925-2009

While the overall impact of foreign students may seem modest, their influence on doctoral programs in general and particularly in some sub-fields in the hard sciences is anything but. Table 8B 
lists the fraction of doctorates awarded to foreign students between 1998 and 2008. Foreign students now earn more than $30 \%$ of all doctorates, and more than half of all Ph.D.s in math and engineering now go to foreign students.

There is a tremendous amount of variance across fields, with much lower foreign representation in the non-science and engineering fields (16.5\%). Mathematical ability and language issues appear to play some role in the choice of degree. Foreign students receive almost half of all U.S. doctorates in physics but much less in the biological sciences (28.7\%). Psychology, a very large degree-awarding program in the United States and a science with both natural and social science arms, awarded only $7.3 \%$ of its degrees to foreign students. ${ }^{11}$

Table 9 provides another perspective by listing the percent of American foreign students by region and country of birth for academic years 1980-81, 2000-2001, and 2008-2009. The most dramatic trend involved Asian students who have been increasing by about 100,000 per decade during that time frame, doubling their proportionate representation from $30 \%$ to over $60 \%$. Not surprisingly, two countries stand out above all others—China and India. In 1980, there were fewer than 3,000 Chinese students studying in the United States-today there are almost 100,000. Similarly, the numbers of Indian students increased over this period from 9,000 to over 100,000. South Korean experienced a ten-fold increase in students studying in the United States. In the rest of the world, total numbers of European and African students stabilized during the last decade. The main area of decline was the Middle East and, within the Middle East, in particular Iran.

The growing numbers of foreign students receiving doctoral degrees from American universities should be viewed in the larger context of a world-wide surge in the demand for degrees beyond the baccalaureate and increasing competition among a relatively few but a growing set of countries (the United Kingdom, United States, France, Germany, Japan, Australia) for these students. 
The surge in demand for science and engineering degrees reflects the strong economic growth in Asia and Europe with only a relatively small part of this demand filled by American institutions. In large part, internal supply in Asia and Europe has responded to meet this demand. For example, in 1999 there were 190,000 doctoral degrees awarded world wide in science and engineering and only 45,000 of them were earned in the United States. Nor is the United States unique in the presence of foreign students in its advance degree programs. To cite just one example, $44 \%$ of doctoral engineering degrees in the United Kingdom were earned by foreign students-the comparable numbers in the United States and France were 49\% and 30\% respectively.

In most science fields, American top universities continue to rank among the world's elite, especially in their research function. These elite American universities produce a disproportionate number of the best of the next generation of scientists. Many of these trained scientists are now not Americans, and this may prove to be the principal legacy of the penetration of foreign students into American universities. The exact contours of that legacy are not yet clear, but the era of dominance of American-born scholars in research in many fields is most likely coming to an end. It is less certain what will happen to the dominance of American universities in research. In certain fields at least, the best of the foreign students remain to teach and to do research at American universities in part because universities in their home countries still do not offer the same opportunities for meritbased advancement and research.

\section{Immigrant Education and Generational Assimilation}

Economic mobility for yourself and your children is deeply tied to our immigration history. Until recently, the conventional view was that in terms of generational assimilation the waves of European immigrants who arrived at the end of the $19^{\text {th }}$ century and the beginning of the $20^{\text {th }}$ century 
were an enormous success. The success of more recent immigrant waves, especially for Latino immigrants, was viewed as far more problematic. ${ }^{12}$

To generalize across all birth cohorts, Figure 7 (for men) and Figure 8 (for women) highlight the relative educational progress across generations of the three ethnic groups. In these graphs, the vertical axis represents the number of years of additional schooling between the generations while the horizontal axis indexes the year of birth of immigrants. In these figures, these educational advances can sometimes be measured across all three generations and sometimes only across two generations because the story of the third generation is not yet complete. However, whether

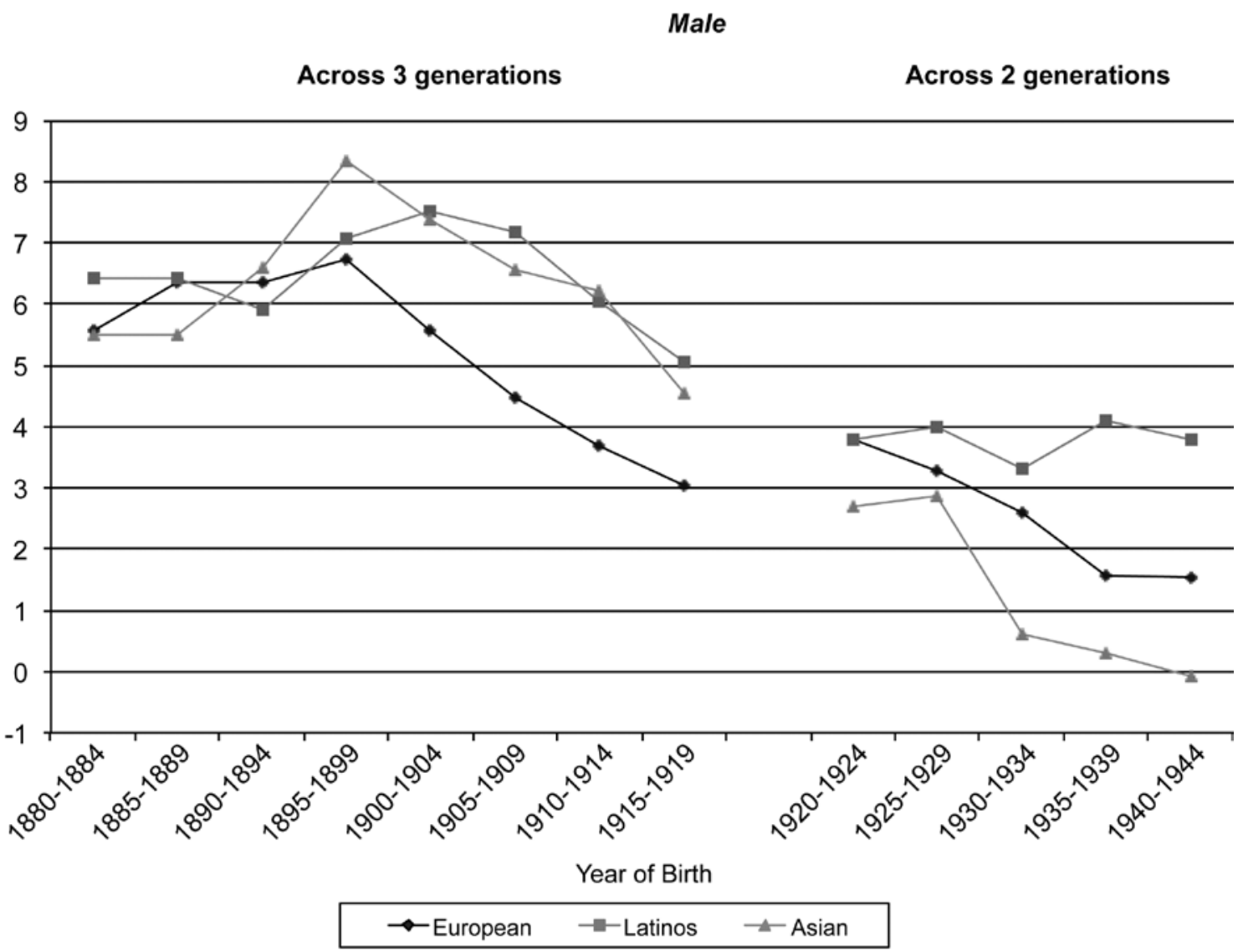

Fig. 7. Generational Progress of Male Immigrants 


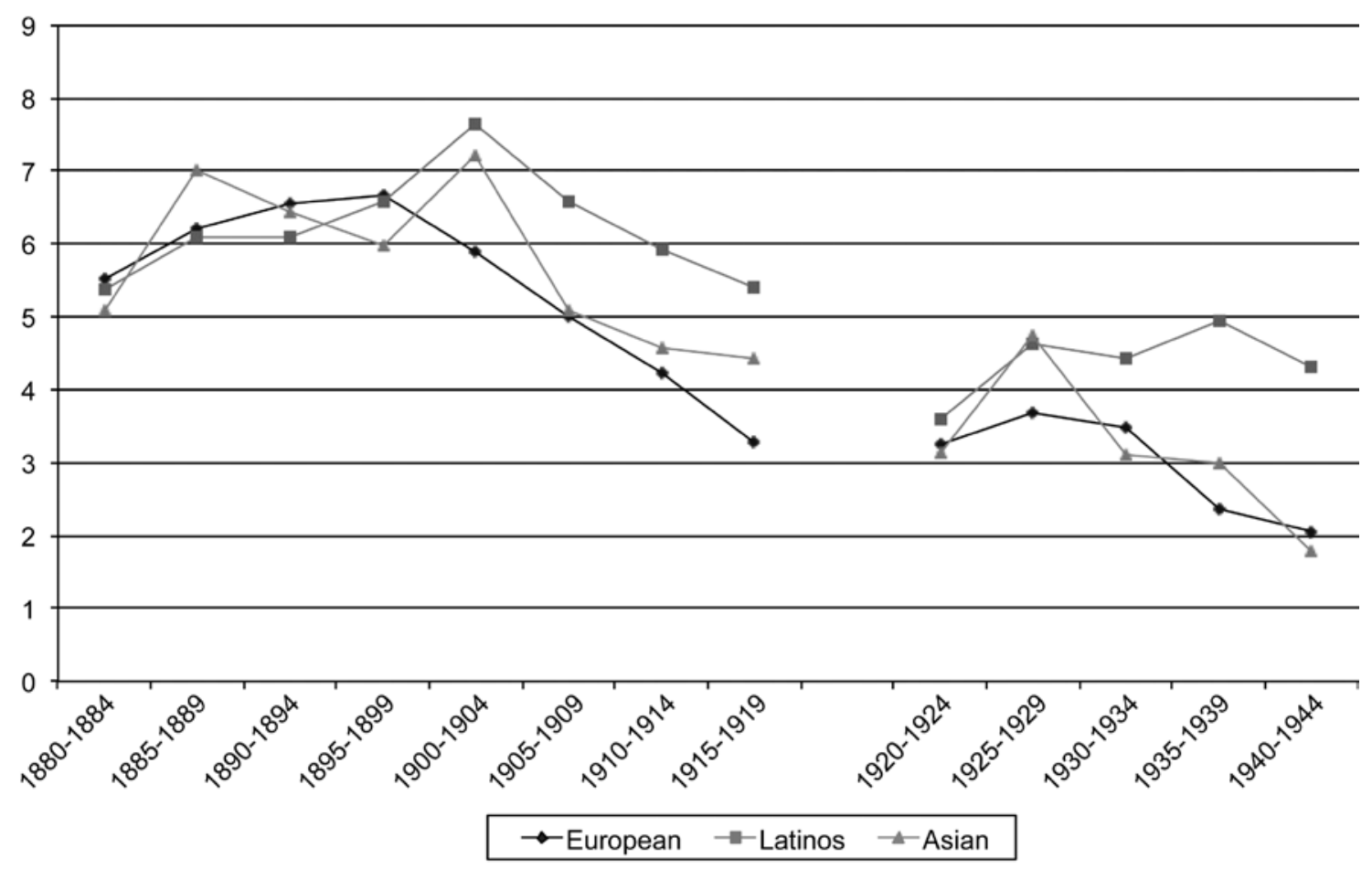

Fig. 8. Generational Progress of Female Immigrants

measured across all three or just two generations and for men and women alike, the education advances made by Latinos are actually greater than those achieved by either European or Asian migrants. There is certainly no evidence from these data that Latinos have lagged behind these other large immigrant groups in their ability to transmit education accomplishments to their children and grandchildren. For all three broad ethnic groups (Europeans, Asian, and Hispanics) educational progress from the immigrant generation to their sons and daughters, and then onto to their grandchildren, is very impressive indeed.

\section{Conclusions}

This paper deals with a number of issues about immigrants to the United States and their education. In part reflecting the reasons why they come to America, immigrants are more highly represented in both the lowest and highest rungs of the education ladder. On average, immigrants 
have less schooling than the native-born, a schooling deficit that reached 1.3 years in 2002. Perhaps as important as the average difference between immigrants and the native-born population, there is considerable diversity in the schooling accomplishments among different immigrant sub-groups. The education of new European and Asian immigrants is higher than that of native-born Americans, while the typical Latino immigrant continues to trail the native-born by about four years of schooling on average.

The education gap of new recent immigrants did rise but only modestly over the last 60 years. This increase was higher among men than among women and appears to be entirely accounted for the increasing fraction of immigrants who are illegal. Legal immigrants appear to have about the same amount of schooling as native-born Americans do, and in the top of the schooling hierarchy have a good deal more. The concern that educational generational progress among Latino immigrants has lagged behind other immigrant groups is largely unfounded. 


\section{Endnotes}

${ }^{1}$ This paper is in many ways an extension and update of Smith (2006a).

${ }^{2}$ These ethnic classifications are based on country of birth (first generation) and country of parents' birth (second generation). For the third plus generations (neither they or their parents were foreign born), Asians are those who claimed Asian race, Hispanics were defined by Hispanic ethnicity, and Europeans were those who were neither one or those and who also were not Black or NativeAmerican using the race variable.

${ }^{3}$ Immigration and Naturalization Serivice (2003; Hofer, Rytina, and Baker (2011).

${ }^{4}$ See Smith and Edmonston (1997), and Pew Hispanic Center (2012) for details.

${ }^{5}$ For a summary of the major legislative changes see chapter 2 in Smith and Edmonston (1997).

${ }^{6}$ In this and other tables, Hispanics include Mexicans.

${ }^{7}$ The small differences for Europeans are not surprising since they comprise such a large fraction of the total.

${ }^{8}$ Other nonimmigrants include temporary visitors for pleasure (tourists) or business, foreign diplomats and officials and their families, and well as a number of other smaller categories.

${ }^{9}$ Tourist visas made up 84\% of all temporary visas for business or pleasure in 2001.

${ }^{10}$ Student visas in Figure 6 include visas for academic students (F1), vocational students (M1), and F2 and M2 visas for spouses and children. However, in 2001 for example, spouses and children make up only $6 \%$ of the total.

${ }^{11} \mathrm{An}$ important issue that has received little rigorous analytical attention is the extent to which these foreign students have displaced American students. Such a question is not answered by just the raw numbers alone. For a thoughtful attempt to address this question, see Borjas (2003). 
${ }^{12}$ This section is based in part on Smith (2003). 


\section{References}

Borjas, G. (1994). “The economics of immigration”. Journal of Economic Literature 32(4), 1667-1717.

Borjas, G. (1995). “Assimilation and changes in cohort quality revisited: What happened to immigrant earnings in the 1980s?” Journal of Labor Economics 13(2), 201-245.

Borjas, G. (2003). "The impact of foreign students on native enrollment in graduate programs”. Unpublished paper.

Historical Statistics of the United States. (2006.) Millennial edition, R. Bache, S. Carter, and R. Sutch (eds.).

Immigration and Naturalization Service. (2003). Estimates of Unauthorized Immigration Population Residing in the United States: 1990 to 2000, Office of Policy and Planning, Washington DC.

Hoefer, M., Rytina, N., Baker, B.C. (2011). Estimates of Unauthorized Immigration Population Residing in the United States: January 2010, Office of Immigration Statistics, Washington, DC.

Jasso, G., Rosenzweig, Mark, and Smith, James P. (2000). “The changing skill of new immigrants to the United States: Recent trends and their determinants,” in Borjas, G. (Ed.), Issues in the Economics of Immigration. University of Chicago Press, Chicago, IL.

Jasso, G., Massey, D., Rosenzweig, M., Smith, J.P. (2000). The New Immigrant Pilot Survey (NIS):

Overview and findings about U.S. immigrants at admission”. Demography 37(1), 127-138.

National Center for Education Statistics. (2010). Digest of Education Statistics. U.S. Department of Education, Washington, DC.

National Center for Science and Engineering Statistics (NCSES). (2011). Science and Engineering Doctorate Awards: 2007-08, National Science Foundation, Washington, DC, NSF 11-321.

National Science Foundation. (2010). Foreign Science and Engineering Students in the United States. National Science Foundation, Washington, DC. 
Office of Immigration Statistics. (2011). 2010 Yearbook of Immigration Statistics. U.S. Department of Homeland Security, Washington, DC.

Passel, J.S., Cohn, D. (2011). Unauthorized Immigrant Population: National and State Trends, 2010. Pew Research Center, Washington, DC.

Pew Hispanic Center. (2012). Statistical Portrait of the Foreign-Born in the United States, 2010.

Smith, J.P., Edmonston, B. (1997). The New Americans: Economic, Demographic, and Fiscal effects of Immigration. National Academy Press, Washington, DC.

Smith. J.P. (2003). “Assimilation across the generations”. American Economic Review 93(2), 315-319.

Smith, J.P. (2006a). “Immigrants and their education,” in Hanushek E., Welch, F. (Eds.), Handbook of the Economics of Education, vol. 1, pp. 156-187. Elsevier B.V., Amsterdam.

Smith, James P. (2006b). “Immigrants and the labor market”. Journal of Labor Economics 24(2):203-233.

U.S. Immigration and Naturalization Service. (2001). Statistical Yearbook of the Immigration and Naturalization Service. Washington, DC. 
Table 1

A. Schooling Distributions of Native-Born and Foreign Populations-2010 CPS

\begin{tabular}{|c|c|c|c|}
\hline \multirow[b]{2}{*}{ Schooling } & \multicolumn{3}{|c|}{ All } \\
\hline & Foreign-Born & Native-Born & Recent Foreign-Born \\
\hline Less than 5 years & 5.6 & 0.4 & 6.2 \\
\hline 5-8 years & 11.9 & 2.3 & 10.2 \\
\hline 9-11 years & 8.9 & 6.0 & 7.6 \\
\hline 12 years & 27.4 & 33.8 & 26.3 \\
\hline $13-16$ years & 35.1 & 47.3 & 37.0 \\
\hline 17-18 years & 7.6 & 7.6 & 10.1 \\
\hline $19+$ years & 3.5 & 2.8 & 2.6 \\
\hline Mean years & 12.27 & 13.59 & 12.53 \\
\hline All Men & 12.32 & 13.59 & 12.64 \\
\hline All women & 12.21 & 13.59 & 12.42 \\
\hline \multicolumn{4}{|c|}{$\begin{array}{l}\text { Source: Calculations by author using the } 2010 \text { March CPS for all persons } 25 \text { and over. The recent } \\
\text { foreign-born are those who migrated within the last five years. }\end{array}$} \\
\hline \multicolumn{4}{|c|}{ B. Schooling Distributions of Native-Born and Foreign Populations-2002 CPS } \\
\hline & \multicolumn{3}{|c|}{ All } \\
\hline Schooling & Foreign-Born & Native-Born & Recent Foreign-Born \\
\hline Less than 5 years & 6.4 & 0.7 & 7.4 \\
\hline 5-8 years & 14.1 & 3.5 & 12.8 \\
\hline 9-11 years & 7.9 & 7.4 & 6.9 \\
\hline 12 years & 26.9 & 34.4 & 23.9 \\
\hline 13-16 years & 34.9 & 45.2 & 34.9 \\
\hline $17-18$ years & 6.4 & 6.3 & 10.0 \\
\hline $19+$ years & 3.6 & 2.6 & 4.3 \\
\hline Mean years & 12.00 & 13.31 & 12.31 \\
\hline All Men & 12.15 & 13.39 & 12.24 \\
\hline All Women & 11.85 & 13.23 & 12.32 \\
\hline
\end{tabular}

Source: Calculations by author using the 2002 March CPS for all persons 25 and over. The recent foreign-born are those who migrated within the last five years. 
Table 2.A

Schooling Distributions of Native-Born and Foreign Populations-2010 CPS

\begin{tabular}{lcccccc}
\hline & \multicolumn{2}{c}{ Asian } & Recent & & \multicolumn{2}{c}{ European } \\
Schooling & Foreign-Born & Native-Born & $\begin{array}{c}\text { Foreign-Born } \\
\text { Recent Foreign- }\end{array}$ & Foreign-Born & Native-Born & Born \\
\hline Less than 5 years & 3.4 & 0.5 & 6.2 & 1.8 & 0.2 & 1.7 \\
5-8 years & 3.5 & 2.2 & 3.3 & 4.5 & 1.9 & 1.3 \\
9-11 years & 3.7 & 2.1 & 3.8 & 3.4 & 4.9 & 4.9 \\
12 years & 21.3 & 20.7 & 17.7 & 26.7 & 33.1 & 29.5 \\
13-16 years & 47.3 & 59.0 & 47.5 & 47.3 & 48.4 & 46.2 \\
17-18 years & 14.7 & 9.2 & 17.8 & 10.4 & 8.4 & 11.8 \\
19+ years & 6.2 & 6.3 & 3.7 & 6.0 & 3.1 & 4.7 \\
Mean years & 14.22 & 14.54 & 14.07 & 13.89 & 13.77 & 14.05 \\
All men & 14.70 & 14.51 & 14.33 & 14.22 & 13.80 & 14.48 \\
All women & 13.82 & 14.57 & 13.89 & 13.60 & 13.76 & 13.61 \\
\hline
\end{tabular}

\begin{tabular}{lccc}
\hline Schooling & Foreign-Born & Native-Born & $\begin{array}{c}\text { Recent } \\
\text { Foreign-Born }\end{array}$ \\
\hline Less than 5 years & 8.9 & 1.8 & 8.6 \\
5-8 years & 20.7 & 5.1 & 21.1 \\
9-11 years & 14.2 & 11.2 & 13.6 \\
12 years & 30.5 & 36.2 & 32.0 \\
13-16 years & 22.2 & 40.6 & 21.7 \\
17-18 years & 2.5 & 3.6 & 2.2 \\
19+ years & 1.0 & 1.5 & 0.8 \\
Mean years & 10.39 & 12.60 & 10.33 \\
All men & 10.33 & 12.62 & 10.41 \\
All women & 10.46 & 12.57 & 10.24 \\
\hline
\end{tabular}

Source: Calculations by author using the 2010 March CPS for all persons 25 and over. The recent foreign-born are those who migrated within the last five years. 
Table 2.B

Schooling Distributions of Native-Born and Foreign Populations-2002 CPS

\begin{tabular}{lcccccc}
\hline & \multicolumn{3}{c}{ Asian } & \multicolumn{3}{c}{ European } \\
\multicolumn{1}{c}{ Schooling } & Foreign-Born & $\begin{array}{c}\text { Native- } \\
\text { Born }\end{array}$ & $\begin{array}{c}\text { Recent } \\
\text { Foreign-Born }\end{array}$ & $\begin{array}{c}\text { Foreign- } \\
\text { Born }\end{array}$ & Native-Born & $\begin{array}{c}\text { Recent } \\
\text { Foreign-Born }\end{array}$ \\
\hline Less than 5 years & 2.8 & 0.2 & 2.4 & 1.9 & 0.4 & 1.9 \\
5-8 years & 5.0 & 2.1 & 3.2 & 6.9 & 2.9 & 5.1 \\
9-11 years & 4.0 & 2.6 & 3.4 & 4.2 & 6.2 & 1.7 \\
12 years & 22.4 & 23.2 & 16.1 & 29.5 & 33.8 & 22.0 \\
13-16 years & 48.4 & 59.4 & 50.3 & 41.7 & 46.8 & 41.1 \\
17-18 years & 11.7 & 6.8 & 18.0 & 10.4 & 7.0 & 19.6 \\
19+ years & 5.7 & 5.6 & 6.5 & 5.5 & 2.9 & 8.9 \\
Mean years & 13.96 & 14.36 & 14.73 & 13.58 & 13.52 & 14.61 \\
All Men & 14.51 & 14.58 & 15,11 & 13.90 & 13.62 & 14.70 \\
All Women & 13.48 & 14.12 & 14.39 & 13.30 & 13.44 & 14.51 \\
\hline
\end{tabular}

\begin{tabular}{lccc}
\hline & \multicolumn{3}{c}{ Hispanics } \\
\cline { 2 - 4 } & & & $\begin{array}{c}\text { Recent } \\
\text { Foreign- } \\
\text { Born }\end{array}$ \\
\hline Schooling & Foreign-Born & Native-Born & 13.3 \\
Less than 5 years & 11.6 & 3.8 & 23.3 \\
5-8 years & 24.9 & 8.9 & 11.6 \\
9-11 years & 12.7 & 12.8 & 25.4 \\
12 years & 27.5 & 34.5 & 22.7 \\
13-16 years & 21.4 & 36.1 & 2.4 \\
17-18 years & 1.3 & 3.0 & 1.4 \\
19+ years & 1.1 & 0.9 & 9.84 \\
\multicolumn{1}{c}{ Mean years } & 9.81 & 11.93 & 9.39 \\
All Men & 9.82 & 12.01 & 10.31 \\
All Women & 9.80 & 11.87 &
\end{tabular}

Source: Calculations by author using the 2002 March CPS for all persons 25 and over. The recent foreign-born are those who migrated within the last five years. 
Table 3

Years of Schooling Completed, by Nativity

\begin{tabular}{|c|c|c|c|c|c|c|c|c|c|}
\hline All & 2010 & 2002 & 1996 & 1990 & 1980 & 1970 & 1960 & 1950 & 1940 \\
\hline U.S. born & 13.59 & 13.31 & 12.99 & 12.61 & 11.78 & 10.84 & 10.01 & 9.43 & 8.77 \\
\hline Foreign born & 12.27 & 12.00 & 11.51 & 11.31 & 10.59 & 8.97 & 7.74 & 7.46 & 6.68 \\
\hline $1-5$ years in US & 12.53 & 12.32 & 11.73 & 11.65 & 11.25 & 10.36 & 9.95 & n.a. & 8.90 \\
\hline \multicolumn{10}{|l|}{ Asian } \\
\hline Foreign born & 14.22 & 13.96 & 13.28 & 12.94 & 13.17 & 11.32 & 8.37 & 7.24 & 7.76 \\
\hline $1-5$ years in US & 14.07 & 14.73 & 13.13 & 12.90 & 12.50 & 13.46 & 12.08 & n.a. & 10.44 \\
\hline \multicolumn{10}{|l|}{ “Europeans” } \\
\hline U.S. born & 13.77 & 13.52 & 13.18 & 12.82 & 12.02 & 11.11 & 10.34 & 9.79 & 9.18 \\
\hline Foreign born & 13.89 & 13.58 & 12.89 & 11.94 & 10.29 & 8.99 & 7.83 & 7.39 & 6.74 \\
\hline \multicolumn{10}{|l|}{ Hispanics } \\
\hline U.S. born & 12.60 & 11.93 & 11.52 & 11.58 & 9.80 & 9.47 & 7.39 & 7.22 & 5.79 \\
\hline Foreign born & 10.39 & 9.81 & 9.27 & 9.23 & 8.91 & 7.91 & 5.99 & 5.79 & 4.71 \\
\hline $1-5$ years in US & 10.33 & 9.84 & 8.41 & 9.14 & 8.26 & 8.40 & 7.23 & n.a. & 7.25 \\
\hline \multicolumn{10}{|l|}{ Mexican } \\
\hline U.S. born & n.a. & n.a. & n.a. & 11.15 & 9.50 & 8.33 & 6.80 & 5.81 & 4.28 \\
\hline Foreign born & 9.51 & 8.66 & 7.93 & 7.71 & 6.74 & 5.59 & 4.39 & 4.53 & 3.97 \\
\hline $1-5$ years in US & 9.56 & 8.53 & 7.52 & 7.83 & 6.33 & 5.93 & 4.58 & n.a. & 6.06 \\
\hline
\end{tabular}

Source: Calculations by author from 1940-1990 decennial Censuses, 1996 and 2010 March CPS. Sample those 25 and above. 
Table 4

Recent Trends in Immigrant Schooling

\begin{tabular}{|c|c|c|c|c|c|}
\hline & All & Asians & Europeans & Hispanics & Mexicans \\
\hline \multicolumn{6}{|l|}{$\begin{array}{l}\text { Time since } \\
\text { immigration }\end{array}$} \\
\hline & \multicolumn{5}{|c|}{2010 CPS } \\
\hline $2006-2010$ & 12.53 & 14.07 & 14.05 & 10.33 & 9.56 \\
\hline 2000-2005 & 12.07 & 14.64 & 14.66 & 10.15 & 9.37 \\
\hline 1996-1999 & 12.15 & 14.83 & 14.81 & 10.28 & 9.61 \\
\hline 1990-1995 & 12.09 & 14.19 & 14.59 & 10.33 & 9.60 \\
\hline \multirow[t]{2}{*}{$<1990$} & 12.38 & 14.01 & 13.46 & 10.56 & 9.50 \\
\hline & \multicolumn{5}{|c|}{2002 CPS } \\
\hline 2000-2002 & 12.51 & 14.70 & 14.77 & 9.87 & 8.37 \\
\hline $1996-2000$ & 12.18 & 14.51 & 14.47 & 9.70 & 8.75 \\
\hline 1990-1996 & 11.71 & 13.63 & 14.41 & 9.55 & 8.74 \\
\hline 1980-1990 & 11.79 & 13.60 & 14.11 & 9.88 & 8.73 \\
\hline \multirow[t]{2}{*}{$<1980$} & 12.15 & 14.07 & 13.01 & 9.95 & 8.56 \\
\hline & \multicolumn{5}{|c|}{1996 CPS } \\
\hline 1990-1996 & 11.56 & 12.80 & 14.21 & 8.69 & 7.89 \\
\hline 1980-1990 & 11.33 & 13.27 & 13.68 & 9.26 & 7.99 \\
\hline$<1980$ & 11.61 & 13.63 & 12.49 & 9.47 & 7.90 \\
\hline
\end{tabular}

Source: Calculations by author. Sample those 25 and above. 
Table 5

New Legal Immigrants Who Attended School in the United States After Receiving Their Green Cards-2003

\begin{tabular}{lllllll}
\hline & & \multicolumn{5}{c}{ Type of Schooling } \\
\hline Age & \% Attended & Regular & Language & GED & Computer & Other \\
\hline $21-30$ & .25 & .433 & .478 & .002 & .010 & .078 \\
$31-40$ & .18 & .264 & .613 & .007 & .016 & .099 \\
$41-60$ & .16 & .157 & .716 & .009 & .022 & .096 \\
$61-80$ & .05 & .059 & .791 & .000 & .041 & .109 \\
All & .18 & .305 & .585 & .005 & .016 & .090 \\
\hline
\end{tabular}

Source: 2003 New Immigrant Survey. Attending is defined as any attendance at the time of the survey. For attendees, a single type of schooling was selected, prioritized by regular, vocational, language and finally other. 
Table 6

Schooling Distributions and Average Years of Legal Immigrants and the

Recent Foreign-Born-2003

\begin{tabular}{lcccc}
\hline & \multicolumn{2}{c}{ All } & \multicolumn{2}{c}{ Asian } \\
$\begin{array}{l}\text { Schooling } \\
\text { characteristic }\end{array}$ & $\begin{array}{c}\text { New Legal } \\
\text { Foreign-Born }\end{array}$ & $\begin{array}{c}\text { Recent } \\
\text { Foreign-Born }\end{array}$ & $\begin{array}{c}\text { New Legal } \\
\text { Foreign-Born }\end{array}$ & $\begin{array}{c}\text { Recent Foreign- } \\
\text { Born }\end{array}$ \\
\hline Less than 5 & 9.5 & 5.9 & 5.4 & 2.6 \\
5-8 years & 13.0 & 13.9 & 9.6 & 5.0 \\
9-11 years & 14.4 & 8.5 & 14.0 & 1.6 \\
12 years & 14.9 & 25.4 & 13.0 & 18.8 \\
13-16 years & 29.1 & 34.9 & 35.3 & 50.7 \\
17-18 years & 11.9 & 8.4 & 14.7 & 16.6 \\
19+ years & 7.3 & 3.0 & 8.1 & 4.8 \\
Mean years & 12.1 & 12.2 & 13.2 & 14.5 \\
\hline
\end{tabular}

\begin{tabular}{|c|c|c|c|c|}
\hline \multirow[b]{2}{*}{ Schooling } & \multicolumn{2}{|c|}{ European } & \multicolumn{2}{|c|}{ Hispanics } \\
\hline & $\begin{array}{l}\text { New Legal } \\
\text { Foreign-Born }\end{array}$ & $\begin{array}{c}\text { Recent } \\
\text { Foreign-Born }\end{array}$ & $\begin{array}{c}\text { New Legal } \\
\text { Foreign-Born }\end{array}$ & $\begin{array}{l}\text { Recent Foreign- } \\
\text { Born }\end{array}$ \\
\hline Less than 5 & 1.5 & 2.0 & 16.1 & 9.5 \\
\hline 5-8 years & 2.7 & 3.8 & 20.8 & 23.7 \\
\hline 9-11 years & 11.7 & 1.5 & 17.5 & 15.2 \\
\hline 12 years & 13.3 & 25.9 & 15.9 & 28.0 \\
\hline 13-16 years & 39.4 & 49.6 & 19.9 & 20.2 \\
\hline 17-18 years & 18.0 & 13.4 & 6.2 & 2.4 \\
\hline 19+ years & 13.4 & 4.5 & 3.6 & 0.9 \\
\hline \multirow[t]{2}{*}{ Mean years } & 14.8 & 14.3 & 10.0 & 10.0 \\
\hline & \multicolumn{2}{|c|}{ Non-Mexican Hispanics } & \multicolumn{2}{|c|}{ Mexicans } \\
\hline Schooling & $\begin{array}{c}\text { New Legal } \\
\text { Foreign-Born }\end{array}$ & $\begin{array}{c}\text { Recent } \\
\text { Foreign-Born }\end{array}$ & $\begin{array}{c}\text { New Legal } \\
\text { Foreign-Born }\end{array}$ & $\begin{array}{c}\text { Recent Foreign- } \\
\text { Born }\end{array}$ \\
\hline Less than 5 & 12.2 & 6.4 & 22.2 & 11.6 \\
\hline 5-8 years & 18.1 & 13.8 & 25.0 & 30.7 \\
\hline 9-11 years & 15.5 & 10.0 & 20.5 & 18.8 \\
\hline 12 years & 17.8 & 35.6 & 12.9 & 22.7 \\
\hline 13-16 years & 24.3 & 28.6 & 13.3 & 14.3 \\
\hline $17-18$ years & 7.7 & 4.2 & 4.0 & 1.3 \\
\hline 19+ years & 4.5 & 1.4 & 2.1 & 0.5 \\
\hline Mean years & 10.9 & 11.5 & 8.5 & 9.0 \\
\hline
\end{tabular}

Note: Recent Immigrants are from the 2003 NIS and the recent foreign-born are from the 2003 CPS. The recent foreign-born entered between 1998-2003. 
Table 7.A

Years of Schooling Completed Among Immigrants Aged 25 Years and Over at Admission, by Visa Class and Adjustee Status

NIS-2003

\begin{tabular}{|c|c|c|c|c|c|c|}
\hline \multirow{3}{*}{$\begin{array}{l}\text { Percent by region of origin } \\
\text { Visa Class }\end{array}$} & \multirow{2}{*}{\multicolumn{2}{|c|}{$\begin{array}{l}\text { All } \\
\text { NA }\end{array}$}} & \multirow{2}{*}{\multicolumn{2}{|c|}{$\begin{array}{c}\text { Asian } \\
31.0\end{array}$}} & \multirow{2}{*}{\multicolumn{2}{|c|}{$\begin{array}{c}\text { European } \\
13.7\end{array}$}} \\
\hline & & & & & & \\
\hline & Mean & Percent & Mean & Percent & Mean & Percent \\
\hline Spouse of U.S. citizen & 13.4 & 32.4 & 13.9 & 26.1 & 15.6 & 34.4 \\
\hline Spouse of Permanent Resident & 8.0 & 2.8 & 11.5 & 1.2 & 11.0 & 0.1 \\
\hline Parent of (adult) U.S. citizen & 7.6 & 13.6 & 9.6 & 16.1 & 12.1 & 7.1 \\
\hline Sibling, principal and spouse & 11.7 & 7.3 & 11.7 & 17.2 & 11.0 & 1.8 \\
\hline Family -other & 12.1 & 10.1 & 13.0 & 10.2 & 14.3 & 3.1 \\
\hline Employment, principal & 16.5 & 6.8 & 16.7 & 13.8 & 16.7 & 7.4 \\
\hline Employment spouse and child & 15.7 & 4.1 & 16.1 & 8.9 & 16.4 & 3.3 \\
\hline Refugee/asylee, principal and spouse & 12.5 & 6.9 & 10.2 & 2.9 & 13.1 & 17.9 \\
\hline Diversity, principal and spouse & 14.8 & 7.8 & 14.4 & 3.4 & 15.1 & 25.4 \\
\hline Other Legalization & 8.5 & 8.3 & 13.6 & 0.3 & 15.3 & 0.4 \\
\hline \multicolumn{7}{|l|}{ Adjustee Status } \\
\hline Adjustees & 12.5 & 57.8 & 14.7 & 42.3 & 14.8 & 59.6 \\
\hline New Arrivals & 11.6 & 42.2 & 12.1 & 57.7 & 14.8 & 40.4 \\
\hline \multirow[t]{3}{*}{ All } & 12.1 & & 13.2 & & 14.8 & \\
\hline & \multicolumn{6}{|c|}{ Non-Hispanic } \\
\hline & \multirow{2}{*}{\multicolumn{2}{|c|}{$\begin{array}{l}\text { Hispanic } \\
43.5\end{array}$}} & \multicolumn{2}{|c|}{ Mexican } & \multicolumn{2}{|c|}{ Mexican } \\
\hline \multirow[t]{2}{*}{ Percent by region of origin } & & & & .4 & & 7.1 \\
\hline & Mean & Percent & Mean & Percent & Mean & Percent \\
\hline Spouse of U.S. citizen & 12.0 & 35.3 & 10.7 & 29.3 & 13.2 & 44.5 \\
\hline Spouse of Permanent Resident & 7.2 & 5.3 & 9.9 & 2.1 & 6.3 & 10.2 \\
\hline Parent of (adult) U.S. citizen & 5.1 & 7.1 & 7.2 & 11.0 & 3.5 & 21.7 \\
\hline Sibling, principal and spouse & 10.9 & 3.5 & 11.3 & 4.2 & 10.2 & 2.6 \\
\hline Family- other & 11.4 & 13.7 & 12.0 & 15.5 & 10.2 & 10.8 \\
\hline Employment, principal & 13.4 & 2.1 & 14.3 & 2.2 & 12.0 & 2.0 \\
\hline Employment spouse and child & 11.2 & 1.1 & 11.5 & 1.2 & 10.5 & 0.8 \\
\hline Refugee/asylee, principal and spouse & 12.7 & 4.4 & 12.7 & 7.2 & NA & 0.1 \\
\hline Diversity, principal and spouse & 14.4 & 0.8 & 14.4 & 1.3 & NA & 0.0 \\
\hline Other Legalization & 8.3 & 18.6 & 8.2 & 26.0 & 8.8 & 7.1 \\
\hline Adjustee Status & & & & & & \\
\hline Adjustees & 10.4 & 69.4 & 11.0 & 66.5 & 9.6 & 73.9 \\
\hline New Arrivals & 8.9 & 30.6 & 10.6 & 33.5 & 5.6 & 26.1 \\
\hline All & 10.0 & & 10.9 & & 8.5 & \\
\hline
\end{tabular}

Note: Jasso, Massey, Rosenzweig, and Smith (2000). Figures are for all immigrants in the 2003 NIS based on weighted data. 
Table 7.B

NIS-Pilot-1996

\begin{tabular}{|c|c|c|c|c|c|c|}
\hline \multirow{2}{*}{$\begin{array}{l}\text { Percent by region of origin } \\
\text { Visa Class }\end{array}$} & \multicolumn{2}{|c|}{$\begin{array}{l}\text { All } \\
\text { NA }\end{array}$} & \multicolumn{2}{|c|}{$\begin{array}{c}\text { Asian } \\
29.7\end{array}$} & \multicolumn{2}{|c|}{$\begin{array}{c}\text { European } \\
22.4\end{array}$} \\
\hline & Mean & Percent & Mean & Percent & Mean & Percent \\
\hline Spouse of U.S. citizen & 13.6 & 28.8 & 14.6 & 19.7 & 15.1 & 22.8 \\
\hline Spouse of Permanent Resident & 10.0 & 10.8 & 14.6 & 6.1 & 12.0 & 4.7 \\
\hline Parent of (adult) U.S. citizen & 7.4 & 10.7 & 9.7 & 11.6 & 9.8 & 3.4 \\
\hline Sibling, principal and spouse & 13.5 & 6.2 & 13.6 & 15.7 & 12.0 & 1.3 \\
\hline Family- other & 12.2 & 11.3 & 12.3 & 12.2 & 13.7 & 8.7 \\
\hline Employment, principal & 16.5 & 9.0 & 17.2 & 12.2 & 16.9 & 12.3 \\
\hline Employment spouse and child & 15.4 & 5.3 & 15.4 & 9.4 & 15.3 & 7.3 \\
\hline Refugee/asylee, principal and spouse & 12.7 & 10.4 & 11.8 & 11.1 & 13.3 & 24.1 \\
\hline Diversity, principal and spouse & 14.7 & 6.3 & 15.3 & 1.5 & 14.9 & 12.7 \\
\hline \multicolumn{7}{|l|}{ Adjustee Status } \\
\hline Adjustees & 13.3 & 57.7 & 14.7 & 45.8 & 14.5 & 67.9 \\
\hline New Arrivals & 11.7 & 42.3 & 12.8 & 54.2 & 14.4 & 32.1 \\
\hline \multirow[t]{3}{*}{ All } & 12.6 & & 13.7 & & 14.4 & \\
\hline & \multicolumn{6}{|c|}{ Non-Mexican } \\
\hline & \multirow{2}{*}{\multicolumn{2}{|c|}{$\begin{array}{c}\text { Hispanic } \\
32.4\end{array}$}} & \multirow{2}{*}{\multicolumn{2}{|c|}{$\begin{array}{c}\text { Hispanic } \\
19.7\end{array}$}} & \multicolumn{2}{|c|}{ Mexican } \\
\hline \multirow[t]{2}{*}{ Percent by region of origin } & & & & & & 2.7 \\
\hline & Mean & Percent & Mean & Percent & Mean & Percent \\
\hline Spouse of U.S. citizen & 12.2 & 38.0 & $` 11.8$ & 41.1 & 12.8 & 33.1 \\
\hline Spouse of Permanent Resident & 8.2 & 21.8 & 10.8 & 10.7 & 7.1 & 39.0 \\
\hline Parent of (adult) U.S. citizen & 5.4 & 14.8 & 6.6 & 12.2 & 4.2 & 18.9 \\
\hline Sibling, principal and spouse & 8.8 & 2.3 & 9.7 & 2.3 & 7.5 & 2.4 \\
\hline Family- other & 10.6 & 13.0 & 10.6 & 19.0 & 11.0 & 3.6 \\
\hline Employment, principal & 13.0 & 4.5 & 12.3 & 6.1 & 16.3 & 2.0 \\
\hline Employment spouse and child & 14.9 & 1.5 & 15.4 & 1.7 & 13.5 & 1.0 \\
\hline Refugee/asylee, principal and spouse & 12.8 & 2.8 & 12.7 & 4.6 & NA & NA \\
\hline Diversity, principal and spouse & NA & NA & NA & NA & NA & NA \\
\hline \multicolumn{7}{|l|}{ Adjustee Status } \\
\hline Adjustees & 11.2 & 63.9 & 12.1 & 58.5 & 10.0 & 72.1 \\
\hline New Arrivals & 8.3 & 36.1 & 9.3 & 41.5 & 6.0 & 27.9 \\
\hline All & 10.1 & & 10.9 & & 8.8 & \\
\hline
\end{tabular}

Note: Figures are for all immigrants in the NIS-P based on weighted data. . 
Table 8

\section{Enrollment of International Students}

\section{A. By Level of Degree}

\begin{tabular}{|c|c|c|c|c|c|c|}
\hline \multirow[t]{2}{*}{ Academic Level } & \multicolumn{6}{|c|}{ International Students (\% of U.S. Enrollment) } \\
\hline & \multicolumn{2}{|c|}{2001} & \multicolumn{2}{|c|}{2006} & \multicolumn{2}{|c|}{2009} \\
\hline Associate & 67,667 & 1.5 & 68,170 & 1.4 & 77,220 & 1.3 \\
\hline Undergraduate & 193,412 & 4.7 & 187,910 & 4.5 & 214,240 & 4.5 \\
\hline Graduate & 264,749 & 11.2 & 269,380 & 10.7 & 294,080 & 10.7 \\
\hline Total & 525,828 & 3.5 & 525,460 & 3.4 & 585,540 & 3.4 \\
\hline
\end{tabular}

Source: Foreign Science and Engineering Students in the United States, National Science Foundation, NSF 10-234, Table 2, July 2010.

\section{B. Percent of Doctorates Awarded to Foreign Students Holding} Temporary Visas, by Field

\begin{tabular}{lccccc}
\hline & 1998 & 2001 & 2003 & 2006 & 2008 \\
\hline All Science and Engineering & .284 & .311 & .332 & .386 & .384 \\
Engineering & .436 & .506 & .552 & .594 & .571 \\
Science & .242 & .258 & .274 & .320 & .326 \\
Mathematics & .377 & .431 & .443 & .503 & .467 \\
Physics & .353 & .402 & .456 & .518 & .496 \\
Biological Sciences & .226 & .218 & .245 & .278 & .295 \\
Psychology & .046 & .045 & .060 & .074 & .073 \\
Other Social Sciences & .254 & .281 & .294 & .313 & .321 \\
Non-Science and Engineering & .112 & .123 & .143 & .165 & .165 \\
All & .222 & .241 & .260 & .310 & .312 \\
\hline Source: Science and Engineering Doctorate Awards: 2007-08, National Center for Science and \\
Engineering Statistics (NCSES), Table 4, National Science Foundation, NSF 11-321, August 2011 .
\end{tabular}


Table 9

Foreign Students Enrolled in Institutions of Higher Education in the United States by Region, and Selected Countries of Origin

\begin{tabular}{|c|c|c|c|c|c|c|}
\hline & \multicolumn{2}{|c|}{$1980-1981$} & \multicolumn{2}{|c|}{$2000-2001$} & \multicolumn{2}{|c|}{$2008-2009$} \\
\hline & Number & Percent & Number & Percent & Number & Percent \\
\hline Asia & 94,640 & 30.3 & 302,058 & 55.1 & 415,000 & 61.8 \\
\hline China & 2,770 & 0.9 & 59,939 & 10.9 & 98,235 & 14.6 \\
\hline South Korea & 6,150 & 2.0 & 45,685 & 8.3 & 75,065 & 11.2 \\
\hline Taiwan & 19,460 & 6.2 & 28,566 & 5.2 & 28,065 & 4.2 \\
\hline India & 9,250 & 3.0 & 54,664 & 10.0 & 103,260 & 15.4 \\
\hline Europe & 28,650 & 9.2 & 93,784 & 17.1 & 87,648 & 13.1 \\
\hline Africa & 38,180 & 12.2 & 34,217 & 6.2 & 36,937 & 5.5 \\
\hline Latin America & 49,810 & 16.0 & 63,634 & 11.6 & 67,731 & 10.1 \\
\hline Middle East & 81,390 & 26.1 & 23,658 & 4.3 & 29,140 & 4.3 \\
\hline North America & 14,790 & 4.7 & 25,888 & 4.7 & 30,107 & 4.5 \\
\hline
\end{tabular}

Source: Digest of Education Statistics, Table 234, National Center for Education Statistics, 2010. 